\title{
European Nordic Countries Stock Market Listed Companies': Factor and Cluster Analysis Approach
}

\author{
Aija Pilvere-Javorska ${ }^{a^{*}}$, Irina Pilvere ${ }^{a}$ \\ ${ }^{a}$ Faculty of Economics and Social Development, Latvia University of Life Sciences and Technologies, Jelgava, 18 Svetes Str, LV-3001, Latvia
}

\begin{abstract}
Public financial markets are crucial in the access to the funding and as a platform for investments to the investors in today's world. Nordic European Union countries such as Sweden, Finland and Denmark are considered to have advanced and well-developed stock markets, while neighboring three Baltic States have rather small stock market. Backbone of the stock market are there listed companies. In this analysis authors attempt to analyze 510 Nordic countries listed companies' absolute value indicators using factor and cluster analysis and to compare results with similar analysis of the Baltic States. Factor and cluster analysis revealed the homogeneity of Nordic countries stock market listed companies' absolute values, authors obtained three complex factors, explaining $89 \%$ of dispersion within the indicators, which in turn resulted in being able to obtain the portrait of Nordic States stock market listed company. Similar results were obtained for Baltic States listed companies, though on different scale. Authors have not seen as detailed analysis of Nordic Stock market on the level of listed companies financial statement analysis. Time period covered in this research of the financials are from 2004 to 2018. The analysis could be beneficial for other researchers focusing on the Nordic region stock market companies and also to the policy makers in the Baltic States, how the neighboring well-developed countries indicators could be interpreted and obtained results used for the enhancement of Baltic States stock market.
\end{abstract}

\section{Keywords:}

Stock Market;

Listed Companies;

Nordic Countries;

Baltic States;

Factor and Cluster Analysis.

\section{Article History:}

$\begin{array}{llll}\text { Received: } & 27 & \text { August } & 2020 \\ \text { Accepted: } & 16 & \text { November } & 2020 \\ \text { Published: } & 01 & \text { December } & 2020\end{array}$

\section{1- Introduction}

Public financial markets play an important role in today's globalized world. They provide public companies with funds to finance their development and allow both enterprises and individual investors to participate in the business success of public companies by becoming their part owners or creditors as well as to protect their savings from inflation and accumulate money for their pensions [1]. However, scientific literature shows that financial markets are functioning in different way [2-6]. Therefore, the integration of financial markets is important to both market participants and policymakers. In integrated markets, capital flows freely to where it will generate the highest return. Integrated financial markets have easier access to foreign capital, but are also more vulnerable to financial crises occurring in other areas of the world [7]. The degree of integration of financial markets is important for international investors. Because it is solely influenced by local information, a completely segmented market provides countryspecific returns to investors [8].

In recent years there has also been a tendency for stock market integration at a deeper level than price convergence. In Europe, these developments include the Euronext merger, the consolidation of the OMX group and ongoing discussions of consolidations of the New York Stock Exchange and Euronext, and potentially NASDAQ and London Stock Exchange. It is natural to explore the relationship between increased merger activity and stock market integration. The level of market integration has important implications for (i) the gains of international diversification

\footnotetext{
* CONTACT: Aija.pilvere-javorska@1lu.lv

DOI: http://dx.doi.org/10.28991/esj-2020-01244
}

(C) 2020 by the authors. Licensee ESJ, Italy. This is an open access article under the terms and conditions of the Creative Commons Attribution (CC-BY) license (https://creativecommons.org/licenses/by/4.0/). 
and (ii) the effect of increased stock market merger activity on market adjustments. Also, since the Nordic and Baltic stock markets are relatively small in size, accompanied with thin trading and potentially low efficiency, the behavior of these markets may be quite different from that of other, larger markets. With regards to the Nordic and Baltic markets, the weak interdependence of stock indices implies that there is still room for international diversification in the area [6].

The Baltic stock exchanges resumed trading in the middle of the 1990s following the collapse of the Soviet Union. During the 2002-2004 period, the Baltic stock exchanges became part of the OMX group, which owns and operates exchanges in the Nordic countries. In 2007, NASDAQ acquired the OMX group, creating the world's largest exchange company, the NASDAQ OMX Group. This acquisition led to the harmonization of trading rules and practices, resulting in increased interest in investment in the Baltic stock exchanges. EU membership contributes to the accelerated stock market integration of European frontier markets through financial reforms and openness to foreign investors [3]. During the past decade, Baltic and Nordic stock exchanges have moved towards a harmonization of procedures and common ownership. While the results of this study demonstrate that the Baltic stock markets were apparently segmented before the crisis, they were highly integrated during the crisis [9]. Therefore, in order to develop the relatively new Baltic States stock market, it is necessary to study in detail the developed Nordic countries stock market in order to gain experience and find solutions for development and further integration, taking into account their geographical location, economy and historical cooperation.

In authors' opinion, the experience of the Nordic countries stock market listed companies absolute value indicators detailed and comprehensive analysis is valuable to compare its results with Baltic States stock market listed companies' financial analysis. The results of the study could contribute in the future to the preparation of proposals for policy makers to stimulate Baltic States stock market, both by attracting new companies in the stock market and by attracting investment for their development, which highlights the topicality and novelty of the article. The article is structured in four consecutive parts. Literature Review presents an overview of the paradigm and the importance of stock market, which emphasizes the need for stock market both to the companies listed there and to the investors. Methodology part described detail research methods and data used. Results and Discussions gives the empirical results and present the factor and cluster analysis of the Nordic countries stock market listed companies absolute value indicators in comparison with identical data indicator analysis on 50 Baltic States stock market listed companies. Conclusions focus on the portraying that Nordic countries listed companies do have similarities among them as revealed by factor and cluster analysis, as well as displays the portrait of the average Nordic countries listed company. These results and comparison to the similar analysis on Baltic States listed companies, could serve to policy makers as a tool with authors' recommendation for the enhancement of the Baltic States stock market.

\section{2- Literature Review}

The degree of integration of financial markets is important for international investors. Because it is solely influenced by local information, a completely segmented market, provides country-specific returns to investors. However, when a local market is integrated with foreign markets, its conditional mean and variance should be influenced by foreign impacts. Over the last few decades, the liberalization and integration of financial markets have increased the capital flow of emerging economies. Stock returns in emerging markets are usually influenced by those of developed markets [10]. During the past few decades, foreign investments have become easier and more cost efficient to conduct. The general liberalization of administrative and legal restrictions on the financial markets has provided investors a much larger investment opportunity set than ever before [11]. In Europe scientists' analyses stock markets in different regions. According Brännäs and Soultanaeva (2011) emerging markets in Central and Eastern Europe display differences in sensitivity to the risk factors that are affecting the return generating process. This behavior may be caused by such factors as industry composition, ownership and trade structure. Overall findings suggest that there are substantial differences among Baltic stock markets, with respect to market adjustment to information arriving from abroad [2]. But Horvath and Petrovski (2013) stress that the financial systems in Central European and South Eastern European countries are largely bank-based, the analysis of stock market developments can still provide useful insights. First, it may help policy makers understand the nature of cross-country shock transmission in a timely fashion since unlike many other economic series, stock market data are available at a high frequency. Similarly, it may be useful to investment managers for international portfolio diversification. Second, although the stock markets in these countries are relatively small in size, they still possess a predictive power for future economic activity and prices [12]. Similar conclusions reached also Beck and Levine (2002), Bóta and Ormos (2014), Niţoi and Pochea (2016), Pradhan et al. (2019) and Orlowski (2020) [13-17].

Nordic, including, Scandinavian stock market has been widely researched in scientific literature. Dengjun (2015) concludes that the evidenced information about determinants of the interdependence between Nordic stock markets is sending strong signals to investors to enhance their investment strategies [18]. Malkamäki et al. (1993) stresses that the ongoing internationalization may well have significant effects on the returns behavior of Scandinavian stock markets, in particular in Norway, Denmark and Finland. The Swedish market is found to be the leading one of the 
four, while the other three appear to have no significant influence on other markets. Malkamäki et al. (1993) results do not indicate full integration of information between Scandinavian stock markets [4]. Antell and Vaihekoski (2012) believe the institutional features and the particular sample period make the Finnish and Swedish stock markets unique test laboratories for currency risk within the conditional international asset pricing framework. However, if investors diversify across countries, the multilateral risk could be more relevant for the pricing of stocks [11]. Ostermark and Aaltonen (1999) study the Granger causality between Scandinavian stock returns and a representative set of global return factors [19]. Pynnonen and Knif (1998) underlines that two Scandinavian markets, the Finnish and the Swedish, which are receiving more and more attention by international analysts in light of the ongoing European integration. For investors, these new markets offer interesting diversification opportunities [20]. As financial products increase in number and complexity, investors have a greater need for information and advice in order to make appropriate decisions. When developing investment strategies, educating clients, and implementing investment plans, it is necessary to consider a number of economic factors, of which perhaps the most crucial is the expectation for future equity returns. Our results highlight the importance of providing financial market experts with neutral and informative data on stock market returns [21]. Kuosmanen et al. (2015) study addresses the predictive association between financial markets and the real economy in the four Nordic countries: Denmark, Finland, Norway and Sweden. Our results suggest that this relationship may differ between neighboring countries even though all of the Nordic countries have a largely equal degree of financial market development, and the countries were similarly affected by the recent severe recession of financial-market origin [22]. Butt and Virk (2015) presents a simplified single period asset-pricing model adjusted for liquidity and tests it for the Nordic markets. The detailed empirical evidence is presented from Finnish test case [23]. Siikanen et al. (2017) examines the stock limit order book characteristics and liquidity around scheduled and non-scheduled company announcements using high frequency multi-level limit order book data of 75 frequently traded stocks listed on exchanges belonging to NASDAQ Nordic for the years 2006 to 2009 [24].

Hegerty (2012) emphasis that it is possible that the Nordic countries on the Baltic Sea-with which the Baltics have enjoyed economic ties for centuries-might also have an important influence on the region's exchange markets. Hegerty (2012) examines this proposition for the Baltic nations, observing their strong economic connections with the Scandinavian countries of the larger Baltic Sea region. It is possible that such small countries might affect their larger neighbor due to their effects on expectations, leading investors to adjust their behavior regarding the common currency as they witness events on the periphery. But the strength of Nordic influence on the Baltics, relative to that of the Eurozone, is the main finding of this study [25]. Ajayi et al. (2018) results show that the Nordic-Baltic markets respond to price innovations from the United States, the United Kingdom, France, and Germany in diverse ways in the period 2001-2013 [26]. Maneschiöld (2006) suggest that international investors can obtain diversification benefits given a long-term investment horizon because of the low degree of integration between the Baltic and international capital markets [5]. However, the major gap both in theoretical and empirical work done in the Baltics is theory and applications of behavioral finance, which has caught an attention of academicians in Scandinavia and led to plenty of research there [1].

\section{3- Methodology}

In this research are presented and analyzed data of listed companies in three Northern European Union countries Finland, Sweden and Denmark, which are listed on Stock Exchanges of Helsinki, Stockholm and Copenhagen. Selected were all the listed companies, and then excluded were financial companies due to their leverage being influenced by different factors compared to non-financial companies. Another significant research limitation is survivorship biases: since data for the listed companies were taken as of July 24, 2019, thus it excludes all previously delisted companies from those Stock Exchanges during reviewed period, which is from 2004 to 2019, as well as it includes only limited data of other listed companies as of the moment of listing, if they were listed later during review period. Overall maximum number of listed companies at any particular reviewed time with data were 547 in the Nordic countries. Next step evaluated obtained indicators and variables results, and eliminated were companies were indicators and variables values resulted as 0 or were missing. Thus, recognized as usable and correct for factor uncluster analysis were 510 Nordic countries stock market listed companies.

20 absolute value indicators are calculated to be able to classify and determine whether there are commonalities and similarities across listed companies' financial profile and the indicators were calculated in the mill.EUR (Table 1). Analysis were performed using IBM SPSS Statistics 26 (Statistical Package for Social Sciences) 2 methods: 1) factor analysis: to precisely identify the relationships between the different companies' capital structure indicators in the Nordic countries stock market listed companies; 2) hierarchical cluster analysis: to obtained an agglomeration of the different companies' capital structure indicators in the Nordic countries stock market listed companies to be used in determining number of clusters with using elbow rule; 3) K-means cluster analysis was used to group Nordic countries stock market companies in the predetermined by elbow rule number of clusters.

Following the same methodology (selected companies, 20 absolute value indicators are calculated, the same study period and the same methods used), data of 50 listed companies in three Baltic States - Estonia, Latvia and Lithuania 
listed companies on Stock Exchanges of Tallinn, Riga and Vilnius were analyzed [27], therefore the obtained research results on 510 Nordic countries stock market listed companies will be compared with the analysis of Baltic States stock market listed companies data.

Table 1. Nordic countries stock market listed companies' absolute value indicators description.

\begin{tabular}{|c|c|c|}
\hline No. & Indicator & Description of Indicator \\
\hline 1 & Market capitalization & Indicates market value of companies shares. \\
\hline 2 & Current assets & $\begin{array}{l}\text { Represent a company's cash and its other assets that are expected to be converted to cash within one year of } \\
\text { the date appearing in the heading of the company's balance sheet. }\end{array}$ \\
\hline 3 & Cash on the balance sheet items & Is company's cash balance at the end of the reporting period. \\
\hline 4 & Total assets & $\begin{array}{l}\text { Are the assets owned by the company that has economic value whose benefits can be derived in the } \\
\text { future. Assets are recorded in the balance sheet of the company. }\end{array}$ \\
\hline 5 & Total equity & $\begin{array}{l}\text { The value left in the company after subtracting total liabilities from total assets. The formula to } \\
\text { calculate total equity is: Equity = Assets - Liabilities. }\end{array}$ \\
\hline 6 & Non-current liabilities & $\begin{array}{l}\text { Include debentures, long-term loans, bonds payable, deferred tax liabilities, long-term lease obligations, and } \\
\text { pension benefit obligations. }\end{array}$ \\
\hline 7 & Long-term borrowing & $\begin{array}{l}\text { Represent money borrowed from banks or other lenders to fund the ongoing operations of a business and } \\
\text { that will not come due within one year. }\end{array}$ \\
\hline 8 & Current liabilities & Is an amount due to be paid to creditors within twelve months. \\
\hline 9 & Short term borrowing & $\begin{array}{l}\text { It is liabilities that represent money borrowed from banks or other institutions to fund the ongoing operations } \\
\text { of a business that will be repaid within one year. }\end{array}$ \\
\hline 10 & Net debt & $\begin{array}{l}\text { Is a liquidity metric used to determine how well a company can pay all of its debts if they were due } \\
\text { immediately. Net debt is calculated by subtracting a company's total cash and cash equivalents from its total } \\
\text { short-term and long-term debt. }\end{array}$ \\
\hline 11 & Sales revenues & $\begin{array}{l}\text { Are the income that a business has obtained from its normal business activities, usually from the sale of } \\
\text { goods and providing services to customers. }\end{array}$ \\
\hline 12 & Annual EBITDA & $\begin{array}{l}\text { Is for any measurement year means consolidated net income before interest, taxes, depreciation, } \\
\text { amortization, extraordinary items. }\end{array}$ \\
\hline 13 & Annual EBIT & $\begin{array}{l}\text { Are earnings before interest and taxes and the indicator together with EBITDA, are indicators of a } \\
\text { company's profitability. }\end{array}$ \\
\hline 14 & Net income & $\begin{array}{l}\text { Is calculated as sales revenues minus cost of goods sold, selling, general and administrative expenses, } \\
\text { operating expenses, depreciation, interest, taxes, and other expenses. }\end{array}$ \\
\hline 15 & Total debt & Is calculated by adding up a company's debt liabilities, which are categorized as short and long-term debt. \\
\hline 16 & Income tax expense & $\begin{array}{l}\text { Is the amount of expense that a business recognizes in an accounting period for the government tax related to } \\
\text { its taxable profit. }\end{array}$ \\
\hline 17 & Cash from operations & $\begin{array}{l}\text { Indicates the amount of money a company brings in from its ongoing, regular business activities, such as } \\
\text { manufacturing and selling goods or providing a service to customers. }\end{array}$ \\
\hline 18 & Cash from investing activities & $\begin{array}{l}\text { Reports how much cash has been generated or spent from various investment-related activities in a specific } \\
\text { period. Investing activities include purchases of physical assets, investments in securities, or the sale of } \\
\text { securities or assets. }\end{array}$ \\
\hline 19 & Cash flow from financing & $\begin{array}{l}\text { Is a section of a company's cash flow statement, which shows the net flows of cash that are used to fund the } \\
\text { company. Financing activities include transactions involving debt, equity, and dividends. }\end{array}$ \\
\hline 20 & Free cash flow to firm & $\begin{array}{l}\text { Is the cash a company produces through its operations, less the cost of investments in assets, depreciation, } \\
\text { taxes, and working capital. }\end{array}$ \\
\hline
\end{tabular}

Factor Analysis is considered an interdependence method for dealing with metric data. In factor analyses we are looking for hidden factors that may explain common sources of variance between variables [28; 29] and it was done in 2 steps: first using hierarchical clustering method and based on the obtained agglomeration schedule and then applying elbow rule, obtained the number of clusters to be used as input for step two - K-means cluster analysis. The concept of $\mathrm{K}$-means cluster is to create $\mathrm{k}$ number - used defined number of clusters - which should group observations in clusters, where observations in one cluster are as similar as possible, while clusters must be as different from each other as possible. Financial indicators were obtained from Bloomberg data base in 2019 and calculated of each sample listed company during research period in 2004-2018 [30]. 


\section{4- Results and Discussion}

\section{4-1- Factor Analysis}

Performing factor analysis first it is necessary verify if the sample is suitable for factor analysis based the judgment on KMO and Bartlett's test. Using 510 Nordic countries stock market listed companies' 20 absolute value indicators, Authors conclude, that KMO of sampling adequacy is 0.885 and Sig. $=0.000$. It means that proportion of variance of analyzed variables might be caused or explained by underlying factors, which is that variability in company data of selected indicators might be causing $88.5 \%$ of chosen financial indicators. Bartlett's test significance indicator is below 0.05 indicates that factor analysis might be applied and useful. It indicates that variables are unrelated. Next step of factor analysis is communalities analysis. All indicators are 0.76 or above. High communalities extraction values indicate that these variables fit well in the factor solution. Obtained communalities matrix indicate that chosen variables fit well in factor solution.

As the rotated component matrix (Varimax rotation) shows that factor interpretation is not unambiguous. Within factor analysis, Authors obtained multi correlation matrix. Significant positive correlation of market capitalization is obtained with 10 and current assets with 12 other absolute value indicators, with 13 indicators correlation was obtained for total assets, non-current liabilities, long-term borrowing, current liabilities, sales revenues, total debt. This is significantly more correlations and strong correlations when compared to the Baltic States absolute value indicators correlation matrix [27]. Contrary to Baltic States where three indicators, namely, cash from investing activities, cash flow from financing and free cash flow to firm do not exhibit any strong correlation or extra strong correlation, in Nordic listed companies all indicators have either strong or extra strong correlation with at least one of the other indicators. Authors' constructed summary of correlation matrix and results are shown in Table 2.

Table 2. Multi correlation matrix results summary of 510 Nordic countries stock market listed companies' absolute value indicators in 2004-2018.

\begin{tabular}{|c|c|c|c|c|}
\hline \multirow{2}{*}{ No. } & \multirow{2}{*}{ Indicator } & \multicolumn{2}{|c|}{ Number of indicators with correlation } & \multirow{2}{*}{$\begin{array}{c}\text { Indicators with extra strong correlation } \\
\qquad>/<+/-0.9\end{array}$} \\
\hline & & Strong $(>/<+/-0.7)$ & Extra strong $(>/<+/-0.9)$ & \\
\hline \multicolumn{5}{|c|}{ Positive correlation } \\
\hline 1 & Market capitalization & 10 & 3 & EBITDA, EBIT, net income \\
\hline 2 & Current assets & 12 & 3 & Cash on balance sheet, current liabilities, sales revenues \\
\hline 3 & $\begin{array}{l}\text { Cash on the balance sheet } \\
\text { items }\end{array}$ & 12 & 2 & Current liabilities, current assets \\
\hline 4 & Total assets & 13 & 7 & $\begin{array}{l}\text { Total equity, non-current liabilities, long-term borrowing, current } \\
\text { liabilities, sales revenues, EBITDA, total debt }\end{array}$ \\
\hline 5 & Total equity & 12 & 3 & Total assets, non-current liabilities, EBITDA \\
\hline 6 & Non-current liabilities & 13 & 5 & Total assets, total equity, long-term borrowing, EBITDA, total debt \\
\hline 7 & Long-term borrowing & 13 & 3 & Total assets, non-current liabilities, total debt \\
\hline 8 & Current liabilities & 13 & 4 & Current assets, cash on the balance sheet, total assets, sales revenues, \\
\hline 9 & Short-term borrowing & 6 & 0 & No indicators \\
\hline 10 & Net debt & 2 & 0 & No indicators \\
\hline 11 & Sales revenues & 13 & 3 & Current assets, total assets, current liabilities \\
\hline 12 & EBITDA & 12 & 6 & $\begin{array}{l}\text { Market capitalization, total assets, total equity, non-current liabilities, } \\
\text { EBIT, net income }\end{array}$ \\
\hline 13 & EBIT & 12 & 3 & Market capitalization, EBITDA, net income \\
\hline 14 & Net income & 12 & 3 & Market capitalization, EBITDA, EBIT \\
\hline 15 & Total debt & 13 & 3 & Total assets, non-current liabilities, long-term borrowing \\
\hline 16 & Income tax expense & 1 & 1 & Cash flow from operations \\
\hline 17 & Cash from operations & 2 & 1 & Income tax expense \\
\hline 18 & Free cash flow to firm & 1 & 0 & No indicators \\
\hline \multicolumn{5}{|c|}{ Negative correlation } \\
\hline 20 & Cash from operations & 2 & 0 & No indicators \\
\hline 21 & $\begin{array}{l}\text { Cash from investing } \\
\text { activities }\end{array}$ & 2 & 0 & No indicators \\
\hline 22 & Cash flow from financing & 2 & 1 & Free cash flow to firm \\
\hline 23 & Free cash flow to firm & 1 & 1 & Cash flow from financing \\
\hline
\end{tabular}


Factor analysis allows based on the quality and sampling of data, which was verified to be suitable and fit well for factor analysis, next step is to determine if and how many complex factors can be obtained from selected 20 absolute value indicators of the Nordic countries stock market listed companies, which explains significant amount of variance in the capital structure of the companies.

Table 3. Factor analysis results of 510 Nordic countries stock market listed companies' absolute value indicators in $2004-2018$.

\begin{tabular}{|c|c|c|c|}
\hline Indicator (explained information, \%) & Factor load & Indicator (explained information, \%) & Factor load \\
\hline \multicolumn{2}{|c|}{ Factor 1. Overall business operations (49.5\%) } & \multicolumn{2}{|c|}{ Factor 2. Cash flow factor $(21.1 \%)$} \\
\hline Cash on the balance sheet items & 0.94 & Cash flow from operations & 0.99 \\
\hline Market capitalization & 0.93 & Income tax expense & 0.92 \\
\hline EBIT & 0.92 & Cash flow from investing & -0.87 \\
\hline Current assets & 0.92 & Free cash flow to firm & 0.86 \\
\hline EBITDA & 0.91 & Cash flow from financing & -0.86 \\
\hline Net income & 0.89 & \multirow{2}{*}{\multicolumn{2}{|c|}{ Factor 3. Debt factor (17.9\%) }} \\
\hline Current liabilities & 0.88 & & \\
\hline Sales revenues & 0.87 & Net debt & 0.95 \\
\hline Total assets & 0.86 & Total debt & 0.72 \\
\hline Total equity & 0.83 & Long-term debt & 0.71 \\
\hline Non-current liabilities & 0.75 & Short-term debt & 0.69 \\
\hline
\end{tabular}

The 20 absolute value indicators, employed in the analysis, initially were grouped in 3 complex factors, same as in Baltic States [27], which met the criterion that their eigen value had to be greater or equal to 1, which thus explained $89 \%$ of the total dispersion (in Baltic States it was 91\%), which is a very high value for this indicator, since only $11 \%$ of variance is explained by other factors. The complex factors, the indicators included in them, and their factor loads are presented in Table 3. Rotation matrix shows grouping of all 3 complex factors. The indicators groups into three complex factors, which are defined by the highest load factor on each indicator.

Complex factor 1 - Overall business operations - explains $49.5 \%$ of the variance of the Nordic countries stock market listed companies' capital structure and this factor groups the largest number of indicators 11 or $55 \%$, this is similar to Baltic States, while Baltic in this group had slightly different indicators and overall, 12 or $60 \%$ of their total number [27]. Complex factor 1 combines indicators from 2 financial statements - balance sheet and income statement, while none from cash flow statement, unlike the case in Baltic States.

The most essential factor load is specific to the variables such as cash in the balance sheet (0.94), market capitalization (0.93), EBIT (0.92), which is contrary to Baltic States, where the most was for income tax expense (0.92), then net income (each 0.92), while similar for market capitalization (0.86) and EBIT (0.84). This complex factor 1 as also with Baltic States, as also indicated in the correlation table, this indicator helps to explain the general business operations and its impact to the revenue generation, as noted previously [27].

The factor analysis produced standardized values of each company for each complex factor, enabling to explain the results obtained - the size and direction of deviation from the average value of 0 . The differences, based on the values obtained, were classified into 3 value levels: 1) a large deviation - factor values smaller than -1 or greater than $1 ; 2$ ) a normal deviation - factor values within a range from -1 to -0.5 and from 0.5 to $1 ; 3$ ) a small deviation - factor values within a range from -0.5 to 0.5 .

The factor analysis reveals that in complex factor 1 there is close a clear grouping in one group of the companies in the group with small deviation -0.5 to 0.5 . This shows that there are unifying factors and financial statement parameters, which are common among Nordic countries stock market listed companies' financials. Complex factor 1 score regression results (Table 4) indicate that majority of companies 459 or $90 \%$ have small deviation (unlike Baltic states had $48 \%$ of companies grouped there [27]), normal deviation have 24 companies or 5\%, but 27 companies or $5 \%$ has a large deviation from the mean. 
Table 4. Detailed characteristics of Complex factor 1 - Overall business operations.

\begin{tabular}{|c|c|c|}
\hline Value levels & $\begin{array}{l}\text { Number of } \\
\text { companies }\end{array}$ & Characteristics \\
\hline Less than -1 & 3 & $\begin{array}{l}\text { Companies in this group has mean value of } 133 \text { mill.EUR cash, third highest market capitalization - mean value } \\
2181 \text { mill.EUR, EBIT of } 143 \text { mill.EUR, current assets } 536 \text { mill.EUR, EBITDA } 206 \text { mill.EUR, while net income } \\
\text { is } 94 \text { mill. EUR, while total assets } 1145 \text { mill.EUR, Total equity } 599 \text { mill.EUR and non-current liabilities of } 159 \\
\text { mill. EUR and current liabilities } 390 \text { mill.EUR. }\end{array}$ \\
\hline From -1 to -0.5 & 7 & $\begin{array}{l}\text { Here are grouping companies with smallest market capitalization, mean value } 505 \text { mill.EUR, negative EBIT for } \\
\text { only group }-7 \text { mill.EUR, significantly smallest net income among groups } 1 \text { mill.EUR, while positive EBITDA } 9 \\
\text { mill.EUR, total assets } 572 \text { mill.EUR, with total equity of more than half of assets } 306 \text { mill.EUR. Non-current } \\
\text { liabilities } 147 \text { mill.EUR, while current liabilities } 119 \text { mill.EUR. }\end{array}$ \\
\hline From -0.5 to 0.5 & 459 & $\begin{array}{l}\text { Overall average profile for this factor of Nordic companies are grouped here, with the least amount of cash } \\
\text { among the groups, mean value } 37 \text { mill.EUR, market capitalization second lowest of } 663 \text { mill.EUR, EBITDA and } \\
\text { EBIT respectively } 67 \text { mill.EUR and } 44 \text { mill.EUR, sales revenues second lowest } 544 \text { mill.EUR, while net income } \\
\text { of } 30 \text { mill.EUR. Current assets } 225 \text { mill.EUR, current liabilities of } 186 \text { mill.EUR, and non-current liabilities of } \\
183 \text { mill.EUR, while total assets } 694 \text { mill.EUR and total equity around } 40 \% \text { - } 282 \text { mill.EUR }\end{array}$ \\
\hline From 0.5 to 1 & 17 & $\begin{array}{l}\text { The second largest by market capitalization grouped companies with mean value of } 5674 \text { mill.EUR, cash on } \\
\text { balance sheet of } 327 \text { mill.EUR, revenues of } 5534 \text { mill.EUR, EBITDA } 731 \text { mill.EUR, net income of } 341 \\
\text { mill.EUR, total assets } 6252 \text { mill.EUR, current assets } 2147 \text { mill.EUR, total equity } 3108 \text { mill.EUR (50\% of } \\
\text { balance sheet), } 1591 \text { mill. EUR in non-current liabilities and } 1552 \text { mill. EUR in current liabilities. }\end{array}$ \\
\hline More than 1 & 24 & $\begin{array}{l}\text { By far the largest companies of stock market, very far from the other groups, in terms of market capitalization of } \\
21269 \text { mill. EUR, cash rich companies - } 1600 \text { mill.EUR, Total assets } 17638 \text { mill.EUR, total equity } 7425 \text { mill. } \\
\text { EUR, total assets } 17638 \text { mill.EUR, current assets } 7589 \text { mill.EUR, current liabilities } 5310 \text { mill.EUR, non-current } \\
\text { liabilities } 4904 \text { mill.EUR, and sales revenues of } 13304 \text { mill. EUR, EBITDA } 2393 \text { mill.EUR, net income } 1215 \\
\text { mill.EUR. }\end{array}$ \\
\hline
\end{tabular}

Complex factor 2 - Cash flow factor - explains 21.1\% (Table 3) of the variance of the Nordic countries stock market listed companies' capital structure absolute indicators responsible for cash flow statement. This complex factor groups the second largest number of indicators -5 or $25 \%$ of their total number. Complex factor 2 includes indicators almost all relates to cash flow component, with exception of income tax indicator - which is income statement indicator. The most significant load in complex factor 2 are carried by cash flow from operations (0.99), income tax expense (0.92), free cash flow to the firm (0.86) and inverse load of cash flow from investing (-0.87), and cash flow from financing (-0.86). This is logical, since if company is investing and distributing financing cash flow to lenders or owners, then it is reported as negative cash flow.

Complex factor 2 score regression results (Table 5) indicate that majority of companies or same as in complex factor 1 - 459 companies or $90 \%$ have small deviation, this is similar to complex factor 2 in Baltic States - 44 or $88 \%$, normal deviation have 22 companies or $4 \%$, but 29 companies for $6 \%$ has a large deviation from the mean [27].

Table 5. Detailed characteristics of Complex factor 2 - cash flow factor.

\begin{tabular}{|c|c|c|}
\hline Value levels & $\begin{array}{l}\text { Number of } \\
\text { companies }\end{array}$ & Characteristics \\
\hline Less than -1 & 4 & $\begin{array}{l}\text { These companies have } 18 \text { mill.EUR generating in cash flow from operations, } 3.5 \text { mill.EUR in income tax, and as } \\
\text { investing cash flow is } 3 \text { mill.EUR, means that these companies are disposing more assets then purchasing. Cash } \\
\text { flow from financing - } 19 \text { mill.EUR, and free cash flow to firm } 13 \text { mill.EUR. }\end{array}$ \\
\hline From -1 to -0.5 & 8 & $\begin{array}{l}\text { In this group are companies with insufficient free cash flow to the firm to finance its operations }-9 \text { mill.EUR, } \\
\text { small cash flow from operations } 1 \text { mill.EUR. In the meantime, these companies are receiving more cash in } \\
\text { financing rather than repaying, and financing cash flow } 28 \text { mill.EUR, while these companies are investing in their } \\
\text { assets } 25 \text { mill.EUR on average. }\end{array}$ \\
\hline From -0.5 to 0.5 & 459 & $\begin{array}{l}90 \% \text { of companies are grouping here, with sound financial standing, cash flow from operations } 41 \text { mill.EUR, } 8 \\
\text { mill.EUR in income tax, free cash flow to the firm mean value of } 12 \text { mill.EUR, and investing more in the assets } \\
\text { than disposing - mean value of - } 38 \text { mill.EUR and dispersing in financing cash flow either to lenders or } \\
\text { shareholders smaller amounts } 1 \text { mill.EUR. }\end{array}$ \\
\hline From 0.5 to 1 & 14 & $\begin{array}{l}\text { Here are grouped companies are second largest by the cash flow, cash flow from operating }-519 \text { mill.EUR, cash } \\
\text { flow from investing }-318 \text { mill.EUR, cash flow from financing } 161 \text { mill.EUR and free cash flow to the firm with } \\
\text { mean value of } 283 \text { mill.EUR. }\end{array}$ \\
\hline More than 1 & 25 & $\begin{array}{l}\text { Significantly the largest by the cash flow companies are grouped here, cash flow from operations mean value } \\
1817 \text { mill.EUR, free cash flow to the firm } 1003 \text { mill.EUR and investing and financing cash flows respectively: - } \\
925 \text { mill.EUR and }-860 \text { mill.EUR }\end{array}$ \\
\hline
\end{tabular}


Complex factor 3 - Debt factor - explains $17.9 \%$ (Table 3) of the variance of the Nordic countries stock market listed companies' absolute value indicators and this factor groups the smallest number of indicators -4 or $20 \%$ of their total number. All indicators are related to debt component: total debt, long-term debt, short-term debt and net debt, which is a function of cash on the balancing and debt combined. The largest load is carried by net debt (0.95), followed by total debt (0.72), long-term debt (0.71) and short-term debt (0.69).

Complex factor 3 score regression results (Table 6) indicate that majority of companies 444 or $87 \%$ (in Baltic States it was 37 companies or $74 \%$ [27]) have small deviation, normal deviation have 23 companies or $5 \%$, but 43 companies for $8 \%$ has a large deviation from the mean.

Table 6. Detailed characteristics of Complex factor 3 - debt factor.

\begin{tabular}{|c|c|c|}
\hline Value levels & $\begin{array}{l}\text { Number of } \\
\text { companies }\end{array}$ & Characteristics \\
\hline Less than -1 & 9 & $\begin{array}{l}\text { Here are grouped companies, where they have exceedingly more cash compared to residual debt, mean value of } \\
\text { net debt is }-2599 \text { mill.EUR, while total debt } 1403 \text { mill.EUR, and majority is long-term borrowing of } 1087 \\
\text { mill.EUR, while short -term borrowing is } 317 \text { mill.EUR. }\end{array}$ \\
\hline From -1 to -0.5 & 6 & $\begin{array}{l}\text { Here are grouped companies with net debt of } 318 \text { mill.EUR, total debt } 788 \text { mill.EUR, long-term debt dominating } \\
\text { with mean value of } 690 \text { mill.EUR, while short-term debt value being } 113 \text { mill.EUR. }\end{array}$ \\
\hline From -0.5 to 0.5 & 444 & $\begin{array}{l}\text { Majority of companies have smallest, if excluding first group, net debt of } 94 \text { mill.EUR, while total debt is } 132 \\
\text { mill.EUR, which breakdown majority is also in long-term borrowing of } 118 \text { mill.EUR, and short-term debt mean } \\
\text { value is } 38 \text { mill.EUR. }\end{array}$ \\
\hline From 0.5 to 1 & 17 & $\begin{array}{l}\text { These companies have mean net debt of } 960 \text { mill.EUR, where total debt is } 1097 \text { mill.EUR, short-term debt mean } \\
\text { value of } 271 \text { mill.EUR and long-term debt is } 886 \text { mill.EUR. }\end{array}$ \\
\hline More than 1 & 34 & $\begin{array}{l}\text { Here are grouped companies with significantly higher total debt of } 3244 \text { mill.EUR, and net debt } 2678 \text { mill.EUR, } \\
\text { which exceeds any of the previous groups, while their mean short-term debt is } 711 \text { mill.EUR and long-term debt } \\
\text { is } 2759 \text { mill.EUR. }\end{array}$ \\
\hline
\end{tabular}

Therefore, it can be concluded that complex factor 1 relates to Overall business operations indicators, which is linked to company's business, second component is linked to factor of Cash flow, while the third one is linked to the capital structure in the balance sheet that is debt component of the company: Debt factor. This dimension proves that funding type is important factor in both overall running business operations, as a separate component and as a source of actual cash flow.

\section{4-2-Cluster Analysis}

Cluster analysis were done in two steps. Nordic countries stock market listed companies' absolute value indicators analysis out of 510 companies they according to elbow rule were grouped in 3 clusters. It appears that based selected financial statement indicators for 490 stock market listed companies are grouped in same cluster number 2 , representing 96\%, which is a similar result obtained from Baltic States stock market listed companies, where 45 companies out of 50 or $90 \%$ are grouped in the same cluster [27]. This allows to assume that indeed majority of Nordic countries stock market listed companies have absolute value indicator similarities. Anova analysis re-confirms that all variables should be introduced to the cluster analysis (Significance levels are below 0.05).

There are cluster 1 representing 6 companies and cluster 3 representing 14 companies, considered as outliers (or "abnormal" data points according to R.S. King [28], since considered sample size of 510 companies 6 and 15 companies are not enough to form a cluster themselves, they are thus outliers. These companies are:

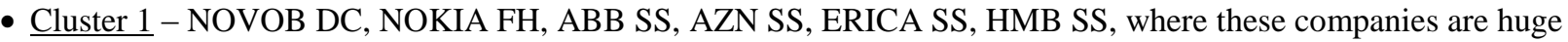
by the market capitalization, compared to the rest, mean value of market cap being 42788 mill.EUR, with total debt of 3300 mill.EUR, revenues of 20071 mill.EUR, and cash flow from operations of 829 mill.EUR.

- $\underline{\text { Cluster } 3}$ - comprise 14 companies, CARLA DC, ISS DC, MAERSKA DC, ORSTED DC, FORTUM FH, STEAV FH, TELIA1 FH, UPM FH, ESSITYA SS, SAND SS, SCAA SS, STEA SS, TELIA SS, VOLVA SS. They are second by size largest companies, with mean market capitalization of 14426 mill.EUR, total debt of 5603 mill.EUR, even more than cluster 1, and significantly more than cluster 2 companies. They generate mean value of 12446 mill.EUR in revenues, and have slightly fewer operating cash flow than cluster 1 companies mean value of 687 mill.EUR.

As Authors mentioned already, the Nordic countries stock market listed companies 490 out of 510, that is $96 \%$ are grouping in cluster 2, those companies' main financial and capital structure defining absolute value indicators are compiled in Table 7. 
Table 7. Nordic countries stock market listed companies' absolute value indicator description in the cluster 2.

\begin{tabular}{|c|c|c|c|c|c|c|}
\hline No. & Cluster 2 indicators & Mean & Min & $\operatorname{Max}$ & STDEV.S. & STDEV.S/Mean, $x$ \\
\hline & \multicolumn{6}{|c|}{ Cluster 2: 490 Companies, 94 from Denmark, 116 from Finland, 280 from Sweden } \\
\hline 1 & Market capitalization & 943.93 & 3.92 & 20885.84 & 2067.37 & 2.19 \\
\hline 2 & Current assets & 335.06 & 1.20 & 7418.70 & 759.35 & 2.27 \\
\hline 3 & Cash on the balance sheet items & 55.94 & 0.11 & 1289.11 & 133.58 & 2.39 \\
\hline 4 & Total assets & 888.66 & 4.25 & 9679.02 & 1583.45 & 1.78 \\
\hline 5 & Total equity & 373.65 & 0.03 & 8343.04 & 749.74 & 2.01 \\
\hline 6 & Non-current liabilities & 215.61 & 0.01 & 2630.79 & 449.13 & 2.08 \\
\hline 7 & Long-term borrowing & 190.61 & 0.00 & 2099.20 & 369.93 & 1.94 \\
\hline 8 & Current liabilities & 258.70 & 0.69 & 6103.30 & 568.46 & 2.20 \\
\hline 9 & Short term borrowing & 59.49 & 0.00 & 1060.98 & 119.31 & 2.01 \\
\hline 10 & Net debt & 163.57 & -7353.44 & 2311.63 & 517.10 & 3.16 \\
\hline 11 & Sales revenues & 768.33 & 0.00 & 14665.02 & 1664.23 & 2.17 \\
\hline 12 & EBITDA & 96.17 & -26.25 & 1925.40 & 205.04 & 2.13 \\
\hline 13 & EBIT & 66.62 & -111.92 & 1593.11 & 157.04 & 2.36 \\
\hline 14 & Net income & 49.83 & -125.36 & 1781.92 & 143.31 & 2.88 \\
\hline 15 & Total debt & 217.84 & 0.00 & 2354.01 & 428.41 & 1.97 \\
\hline 16 & Income tax expense & 26.14 & -60.97 & 2174.08 & 126.05 & 4.82 \\
\hline 17 & Cash from operations & 116.73 & -221.74 & 5304.33 & 439.39 & 3.76 \\
\hline 18 & Cash from investing activities & -78.75 & -4409.61 & 56.43 & 274.78 & -3.49 \\
\hline 19 & Cash flow from financing & -31.86 & -2543.86 & 430.31 & 206.89 & -6.49 \\
\hline 20 & Free cash flow to firm & 53.80 & -320.31 & 4503.30 & 279.47 & 5.19 \\
\hline
\end{tabular}

The cluster analysis provides information on the average portrait of the Nordic countries stock market listed company. The size wise - mean value of total assets is 888 mill. EUR, with market capitalization value of 944 mill. EUR, contrary to Baltic States [27], where market capitalization mean value is less than total asset value, thus representing the discrepancy in company valuations by the market. Mean sales revenues here contrary to Baltic States is less than mean market capitalization and is 768 mill. EUR, while 96 mill. EUR in mean EBITDA value. Total debt mean value is 218 mill.EUR, in this indicator there is one of the smallest deviations as is the case also for Baltic States. Among all indicators, the lowest standard deviation calculated against mean, is for long-term borrowing, total debt, total equity and short-term borrowing, which all are capital structure component of the balance sheet.

Evaluating from the capital structure perspective, the companies mean debt value of 218 mill. EUR is $25 \%$ of total assets, where in Baltic States it was $21 \%$ of total assets' mean value. Short-term borrowing proportion in total debt is only $27 \%$, where in Baltic States it was almost twice higher, that is $50 \%$ of total debt [27].

Largest deviations of standard deviation from the mean are for the following absolute value indicators: cash flow from financing and free cash flow to firm, this indicates that in these two absolute value indicators companies are the most different in their financial standings, this is also the trend with Baltic States listed companies' absolute value indicator cluster results.

\section{5- Conclusions}

The factor and cluster analysis of 510 Nordic countries stock market listed companies 20 absolute value indicators and when Authors' compared it to 50 Baltic States stock marked listed company's analyses, conclusions are following that:

- In Nordic States stock market listed companies based on the absolute value indicators are more homogenously located around mean $90 \%$, or that stock market listed companies are more similar while in Baltic States less than half - $48 \%$ they are more dispersed and different from each other in terms of financial indicator parameters. This indicates also the need and recommendation that Baltic States rather than what is common view in the industry to attract large companies, which still in the Baltic States compared to the Nordic countries are small, but instead Baltic States stock market needs to attract small and medium size companies, to have the focus and being able to differentiate from other markets. Additionally, to consider attracting rather than currently dominating institutional investors, to whom Baltic State stock market listed companies are small, but to work towards local 
retail investor attraction in the same time, which combined with low bank deposit rates and bond yields, if made simpler, cheaper and more accessible, could ensure the so needed volume of stock market;

- Difference with Baltic States is that in Nordic countries stock market companies' analysis based on the complex factor 1, indicates in all groups that mean market capitalization exceeds mean value of total assets. While in Baltic States in some cases market capitalization barely exceeds total equity value, in some cases even not, this means that Baltic States stock market listed companies might be undervalued or improperly valued by the market when compared to the Nordic countries stock market listed companies;

- It appears that based selected financial statement indicators for 490 Nordic Countries stock market listed companies are grouped in same cluster number 2, representing 96\%, which is a similar result obtained from Baltic States stock market listed companies, where 45 companies out of 50 or $90 \%$ are grouped in the same cluster. This allows to assume that indeed majority of Nordic countries stock market listed companies have absolute value indicator similarities;

- The Baltic States, as well as Nordic countries, which were used as a benchmark, that also there are common parameters of Nordic countries stock market listed companies from financial standpoint, when measured in absolute value indicators. The results of this analysis can be used, in order to prepare recommendations to policy makers on how to create stock market in the Baltic states more attractive to companies, based on the Nordic countries stock market listed companies' experience and financial analysis.

\section{6- Funding and Acknowledgements}

The research was supported by the National Research Programme "Latvian Heritage and Future Challenges for the Sustainability of the State" project "Challenges for the Latvian State and Society and the Solutions in International Context (INTERFRAME-LV)". The publication was funded by grant "Strengthening Research capacity in the Latvia University of Life Sciences and Technologies" project No Z39.

\section{7- Conflict of Interest}

The author declares that there is no conflict of interests regarding the publication of this manuscript. In addition, the ethical issues, including plagiarism, informed consent, misconduct, data fabrication and/or falsification, double publication and/or submission, and redundancies have been completely observed by the authors.

\section{8- References}

[1] Raimonds, Lieksnis. "Asset Pricing Problems in the Baltic Financial Markets”. Summary of Doctoral Dissertation. Riga: RTU Publishing House (2013): 67.

[2] Brännäs, Kurt, and Albina Soultanaeva. "Infulence of News from Moscow and New York on Returns and Risks of Baltic States' Stock Markets.” Baltic Journal of Economics 11, no. 1 (March 2011): 109-124. doi:10.1080/1406099x.2011.10840493.

[3] Kiviaho, Jarno, Jussi Nikkinen, Vanja Piljak, and Timo Rothovius. "The Co-Movement Dynamics of European Frontier Stock Markets.” European Financial Management 20, no. 3 (June 27, 2012): 574-595. doi:10.1111/j.1468-036x.2012.00646.x.

[4] Malkamäki, Markku, Teppo Martikainen, Jukka Perttunen, and Vesa Puttonen. "On the Causality and Co-Movements of Scandinavian Stock Market Returns.” Scandinavian Journal of Management 9, no. 1 (March 1993): 67-76. doi:10.1016/09565221(93)90035-q.

[5] Maneschiöld, Per-Ola. "Integration between the Baltic and International Stock Markets." Emerging Markets Finance and Trade 42, no. 6 (December 2006): 25-45. doi:10.2753/ree1540-496x420602.

[6] Nielsson, Ulf. "Interdependence of Nordic and Baltic Stock Markets.” Baltic Journal of Economics 6, no. 2 (December 2007): 9-27. doi:10.1080/1406099x.2007.10840434.

[7] Büttner, David, and Bernd Hayo. "Determinants of European Stock Market Integration." Economic Systems 35, no. 4 (December 2011): 574-585. doi:10.1016/j.ecosys.2010.10.004.

[8] Wang, Ming-Chieh, and Feng-Ming Shih. "Time-Varying World and Regional Integration in Emerging European Equity Markets.” European Financial Management 19, no. 4 (November 13, 2011): 703-729. doi:10.1111/j.1468-036x.2011.00623.x.

[9] Nikkinen, Jussi, Vanja Piljak, and Janne Äijö. "Baltic Stock Markets and the Financial Crisis of 2008-2009." Research in International Business and Finance 26, no. 3 (August 2012): 398-409. doi:10.1016/j.ribaf.2012.03.003.

[10] Wang, Ming-Chieh, and Feng-Ming Shih. "Time-Varying World and Regional Integration in Emerging European Equity Markets.” European Financial Management 19, no. 4 (November 13, 2011): 703-729. doi:10.1111/j.1468-036x.2011.00623.x.

[11] Antell, Jan, and Mika Vaihekoski. "Pricing Currency Risk in the Stock Market: Evidence from Finland and Sweden 19702009." Journal of International Financial Markets, Institutions and Money 22, no. 1 (February 2012): 120-136. doi:10.1016/j.intfin.2011.08.002. 
[12] Horvath, Roman, and Dragan Petrovski. "International Stock Market Integration: Central and South Eastern Europe Compared." Economic Systems 37, no. 1 (March 2013): 81-91. doi:10.1016/j.ecosys.2012.07.004.

[13] Beck, Thorsten, and Ross Levine. "Industry Growth and Capital Allocation: does having a market- or bank-based system matter?" Journal of Financial Economics 64, no. 2 (May 2002): 147-180. doi:10.1016/s0304-405x(02)00074-0.

[14] Bóta, Gábor, and Mihály Ormos. "Development of Stock Market Pricing in Central and Eastern Europe through Two Decades after the Transition.” Empirica 42, no. 4 (August 2, 2014): 685-708. doi:10.1007/s10663-014-9272-0.

[15] Niţoi, Mihai, and Maria Miruna Pochea. "Testing Financial Markets Convergence in Central and Eastern Europe: A NonLinear Single Factor Model.” Economic Systems 40, no. 2 (June 2016): 323-334. doi:10.1016/j.ecosys.2016.02.002.

[16] Pradhan, Rudra P., Mak B. Arvin, Mahendhiran Nair, and Sara E. Bennett. "Inter-Linkages between Competition and Stabilisation Policies in the Banking Sector and Stock Market Development in Europe.” Applied Economics 51, no. 39 (March 27, 2019): 4313-4324. doi:10.1080/00036846.2019.1591603.

[17] Orlowski, Lucjan T. “Capital Markets Integration and Economic Growth in the European Union.” Journal of Policy Modeling 42, no. 4 (July 2020): 893-902. doi:10.1016/j.jpolmod.2020.03.012.

[18] Dengjun, Zhang. "Interdependence between Nordic Stock Markets and Financial Cooperation.” Review of Accounting and Finance 14, no. 2 (May 11, 2015): 172-188. doi:10.1108/raf-03-2013-0036.

[19] Ostermark, Ralf, and Jaana Aaltonen. "Comparing the Causality Patterns between Some Scandinavian Stock Returns and Global Return Factors.” International Journal of Systems Science 30, no. 6 (January 1999): 611-626. doi:10.1080/002077299292128.

[20] Pynnonen, Seppo, and Johan Knif. "Common Long-Term and Short-Term Price Memory in Two Scandinavian Stock Markets." Applied Financial Economics 8, no. 3 (June 1998): 257-265. doi:10.1080/096031098333014.

[21] Kaustia, Markku, Eeva Alho, and Vesa Puttonen. "How Much Does Expertise Reduce Behavioral Biases? The Case of Anchoring Effects in Stock Return Estimates." Financial Management 37, no. 3 (September 2008): $391-412$. doi:10.1111/j.1755-053x.2008.00018.x.

[22] Kuosmanen, Petri, Nasib Nabulsi, and Juuso Vataja. "Financial Variables and Economic Activity in the Nordic Countries." International Review of Economics \& Finance 37 (May 2015): 368-379. doi:10.1016/j.iref.2014.12.008.

[23] Butt, Hilal Anwar, and Nader Shahzad Virk. "Liquidity and Asset Prices: An Empirical Investigation of the Nordic Stock Markets.” European Financial Management 21, no. 4 (September 2015): 672-705. doi:10.1111/eufm.12041.

[24] Siikanen, Milla, Juho Kanniainen, and Jaakko Valli. "Limit Order Books and Liquidity around Scheduled and Non-Scheduled Announcements: Empirical Evidence from NASDAQ Nordic.” Finance Research Letters 21 (May 2017): $264-271$. doi:10.1016/j.frl.2016.12.016.

[25] Hegerty, Scott W. "How Integrated Are the Exchange Markets of the Baltic Sea Region? An Examination of Market Pressure and Its Contagion.” Baltic Journal of Economics 12, no. 2 (January 2012): 109-122. doi:10.1080/1406099x.2012.10840520.

[26] Ajayi, Richard A., Seyed Mehdian, and Ovidiu Stoica. "An Empirical Examination of the Dissemination of Equity Price Innovations between the Emerging Markets of Nordic-Baltic States and Major Advanced Markets." Emerging Markets Finance and Trade 54, no. 3 (February 13, 2018): 642-660. doi:10.1080/1540496x.2017.1419426.

[27] Pilvere-Javorska, A., Pilvere, I., Rivza, B., Rivza, P. "Baltic States Stock Market Listed Companies' Absolute Value Indicators Analysis". IMECONF 3rd International Conference on Research in Management and Economics, 11-13 September 2020, Brussels, Belgium, (2020): 27-39.

[28] King, Ronald S. “Cluster Analysis and Data Mining: An Introduction”. Dulles, Virginia: Mercury Learning \& Information (2015): 316.

[29] Fabrigar, Leandre R., Wegener Duane T. "Exploratory Factor Analysis”. Oxford: Oxford University Press (2012): 159.

[30] Bloomberg L.P. Data base, Bloomberg Terminal (2019) (accessed on 21 October 2019). 